\title{
60S Ribosomal Protein L22
}

National Cancer Institute

\section{Source}

National Cancer Institute. 60S Ribosomal Protein L22. NCI Thesaurus. Code C97763.

$60 S$ ribosomal protein L22 (128 aa, $\sim 15 \mathrm{kDa})$ is encoded by the human RPL22 gene. This protein is involved in the mediation of translation. 